\title{
Low effect of viruses on bacteria in deep anoxic water and sediment of a productive freshwater reservoir
}

\author{
A. S. Pradeep Ram, M. Sabart, D. Latour, T. Sime-Ngando* \\ Laboratoire ‘Microorganismes: Génome et Environnement', UMR CNRS 6023, Université Blaise Pascal, Clermont-Ferrand II,
} 63177 Aubière Cedex, France

\begin{abstract}
The seasonal and vertical distribution of freshwater viruses and the related induced bacterial mortality were determined in the water column down to the surface sediments of the thermally stratified reservoir Lake Grangent, France, between March and November 2007 in relation to environmental parameters. Viral abundance (VA, range $=0.9$ to $3.5 \times 10^{10} \mathrm{l}^{-1}$ ), bacterial abundance (BA), and the frequency of infected cells were significantly higher in the oxic than in the anoxic waters, which was partly related to forcing from the thermal stratification together with vertical changes in dissolved oxygen, ammonia and phytoplankton biomass. BA was the best predictor $\left(\mathrm{R}^{2}=\right.$ 0.78 ) for VA in the oxygenated waters only. The virus-to-bacteria ratio (VBR) yielded less variability and did not differ significantly along the water column (mean $\pm \mathrm{SD}$ value $=5.5 \pm 1.3$ ). In the sediments, both VA and BA were one order of magnitude higher than in the water column with a higher variable VBR ratio $(10.6 \pm 8.9)$. Paradoxically, the frequency of visibly infected bacterial cells (determined from transmission electron microscopy) in the sediments was significantly lower (on average 3- to 7-fold) compared with the water column, which is in agreement with recent benthic reports in geographically contrasting lake environments. On average, viruses destroyed $23 \%$ of bacterial production in the oxygenated surface waters, but only $9 \%$ in deep anoxic waters and $3 \%$ in the sediments. Overall, there was a remarkably low viral influence on heterotrophic bacteria in the anoxic waters and overlying sediments of Lake Grangent, where recurrent shift from summer planktonic to winter benthic phases in cyanobacterial blooms is typical.
\end{abstract}

KEY WORDS: Lakes · Seasonal dynamics · Viruses $\cdot$ Bacteria $\cdot$ Lytic infection $\cdot$ Microbial ecology

\section{INTRODUCTION}

With the discovery of high viral abundance in aquatic environments almost 2 decades ago (Bergh et al. 1989), it is now well established that viruses form an integral component of the microbial food web in a great variety of such environments (Suttle 2007, Middelboe et al. 2008, Wilhelm \& Matteson 2008). They play an important role in the regulation of carbon and nutrient fluxes, food web dynamics and bacterial diversity (Wilhelm \& Suttle 1999, Brussaard et al. 2008, Sime-Ngando \& Colombet 2009). Reports have suggested that viral lysis can account for up to 90 to $100 \%$ of bacterial mortality in some freshwater systems
(Weinbauer \& Höfle 1998, Fischer \& Velimirov 2002), which has led to the conclusion that viral lysis can be a major cause of mortality, comparable with grazinginduced mortality (Wilhelm \& Matteson 2008). Attempts to predict dynamics of virioplankton in aquatic systems have revealed relationships to environmental parameters that affect the abundance and activity of the host, primarily bacterioplankton. Although estimates of viral abundance and infection rates have been made for a variety of aquatic environments, including freshwater, seawater and hypersaline ponds, such investigations pertaining to reservoirs are rare and very limited (Sommaruga et al. 1995, Šimek et al. 2001, Pradeep Ram et al. 2005). Studies in reservoirs 
are important as their artificial origin makes them useful study models, both in terms of understanding phenomena related to eutrophication and for determining the relative importance of the different environmental factors on microbial metabolism. Disturbance frequencies are much higher in reservoirs than in lakes, with rapid, often irregular and large, changes in flushing rates, water level and the stability of the water column (Wetzel 2001). Lack of opportunity to document viral ecology in such systems has resulted in a paucity of knowledge about these environments.

Lake Grangent, is a eutrophic and turbid reservoir located in the Massif Central of France on the upper reaches of the River Loire $15 \mathrm{~km}$ from the city of SaintEtienne. Since 1970, high external phosphorous loading has been causing hypereutrophication of the reservoir, which has led to the recurrence of cyanobacterial blooms of Microcystis aeruginosa in August or sometimes in early June every year (Berthon et al. 1996), with a summer planktonic phase followed by an overwinter benthic phase (Latour et al. 2004). Thermal stratification begins in March with a weak thermocline at $30 \mathrm{~m}$. Euphotic $(<7 \mathrm{~m})$ and aphotic zones differ significantly in terms of temperature, dissolved oxygen, ammonia concentration, organic matter and phytoplankton biomass. Therefore, the factors controlling viral abundance and phage infection can change significantly with depth, as previously inferred from Lake Pavin, France (Colombet et al. 2006).

Our knowledge of the significance of viral lysis for bacterial production in anoxic waters is sparse (Weinbauer \& Höfle 1998, Gobler et al. 2008). Since grazing rates are typically low in anoxic waters (cf. Colombet et al. 2006), other mechanisms such as viral lysis must be responsible for bacterial mortality. So, we hypothesize that bacteriolysis should be much higher in the anoxic compared with the oxic zone, based on the evidence

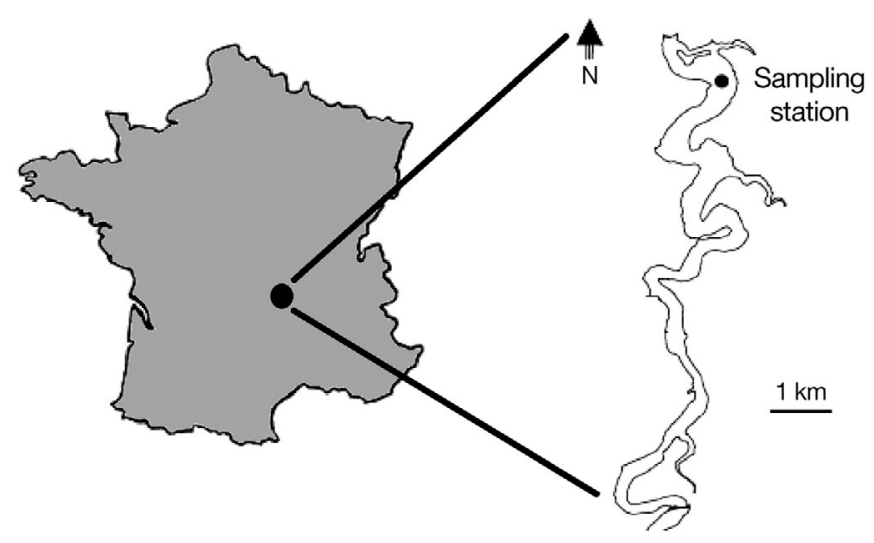

Fig. 1. Location of sampling station in Lake Grangent, France from theoretical (Pedros-Alio et al. 2000) and empirical field (Colombet et al. 2006) investigations. The results of the present study reveal the ecological importance of the depth-related fluctuations of virioplankton abundances and their infection rates linked to physicochemical variables of the water column, which has not yet been explored on a seasonal scale. The study of viral ecology in Lake Grangent is also of interest because only few data are available with regard to the seasonal trends and vertical variations of viral abundance and infectivity in eutrophic waters.

The present study reports on the seasonal and vertical variability of viruses, bacteria and phytoplankton biomass (i.e. chlorophyll a [chl a]) in the water column and water-sediment interface of Lake Grangent from March to November 2007.

\section{MATERIALS AND METHODS}

Sampling. For detailed hydrological and morphological characteristics of Lake Grangent see Latour et al. (2004). Water samples were collected in the downstream part of the reservoir $\left(35^{\circ} 33^{\prime} \mathrm{N}, 75^{\circ} 01^{\prime} \mathrm{E}\right.$, Fig. 1) where blooms have been primarily occurring for the past few years (Giraudet \& Berthon 1999). Samples were collected bimonthly from March to November 2007 using a horizontal 101 Van Dorn bottle. The sampling depths were $0.5,5,10$ and $40 \mathrm{~m}$. Secchi depth $\left(z_{\mathrm{SD}}\right)$ measurements were used to estimate the euphotic depth $\left(z_{\mathrm{eu}}\right)$ according to the relationship: $z_{\mathrm{eu}}=$ $2.42 z_{\mathrm{SD}}$, assuming that $15 \%$ of the incident light is transmitted to the $z_{\mathrm{SD}}$ depth (Wetzel \& Likens 1995). According to the above criteria, $z_{\text {eu }}$ did not exceed $7 \mathrm{~m}$ in the present study, and as a result the sampling depths of 0.5 and $5 \mathrm{~m}$ were considered to be located in the euphotic zone. We also collected samples in the surface sediments (i.e. 0 to $2 \mathrm{~cm}$ of the upper sediments) using a core drill at $42 \mathrm{~m}$ (i.e. $z_{\max }$ ). These samples were cut out and stored in dark bottles before being brought back to the laboratory. All samples were collected in triplicate.

Physicochemical variables. Water temperature and dissolved oxygen profiles were determined in situ using a WTW-OXI-320 multiparameter probe and the values were interpolated through the water column by using SURFER 5.00 (Golden Software). Samples for nutrients, namely dissolved ammonium (as $\mathrm{NH}_{4}-\mathrm{N}$ ) (AFNOR 1990), nitrate (as $\mathrm{NO}_{3}$-N) (Rodier 1996) and soluble orthophosphate (as $\mathrm{PO}_{4}-\mathrm{P}$ ) (Motomizu et al. 1982) were analyzed spectrophotometrically, whereas silica concentration was analyzed colorimetrically by means of standard methods (AFNOR 1990). Chl a concentrations were determined spectrophotometrically (Lorenzen 1967) from samples collected on GF/F filters 
(Whatman) from a $500 \mathrm{ml}$ volume of reservoir water. Pigments were extracted in $90 \%$ acetone overnight in the dark at $4^{\circ} \mathrm{C}$. The supernatant was used to determine the functional chl $a$ and then acidified with $0.1 \mathrm{~N}$ $\mathrm{HCl}$ to estimate phaeopigments.

Bacterial and viral abundances. For the enumeration of virus-like particles and bacteria, water samples were fixed with $0.02 \mu \mathrm{m}$ filtered, buffered alkaline formalin (final concentration, $2 \% \mathrm{v} / \mathrm{v}$ from a $37 \% \mathrm{w} / \mathrm{v}$ solution of commercial formaldehyde). Within $1 \mathrm{~h}$ of sampling, 1 to $2 \mathrm{ml}$ subsamples were filtered (under $<15 \mathrm{kPa}$ vacuum) through $0.02 \mu \mathrm{m}$ pore size Anodisc filters (Whatman), with $1.2 \mu \mathrm{m}$ pore size cellulose acetate backing filters. After staining with SYBR Green I fluorochrome (Molecular Probes Europe) (final dilution, $2.5 \times 10^{-3}$ fold) as described by Noble \& Fuhrman (1998), filters were air dried on absorbent paper, mounted on slides and covered with glass coverslips with the mountant Glycerol/PBS solution (i.e. Citifluor) amended with a special antifading solution, i.e. ca. $20 \%$ (v/v) of Vecta Shield (Vector Laboratories). This amendment significantly reduced fading of the fluorochrome and gave highly stable fluorescence (Pradeep Ram et al. 2005). When not analyzed immediately, slides were stored at $-20^{\circ} \mathrm{C}$ until needed for counting under a model 300F epifluorescent microscope (Leica DC). Bacteria were distinguished from virus-like particles on the basis of their relative size and brightness. A blank was routinely examined to control for contamination of the equipment and reagents.

For sediment samples, 2 to $4 \mathrm{~g}$ of sediment (with a precision of $0.005 \mathrm{~g}$ ) from the top layer (0 to $2 \mathrm{~cm}$ depth) of the core sample was transferred to a $50 \mathrm{ml}$ centrifuge tube, and $4 \mathrm{ml}$ of virus-free $(0.02 \mu \mathrm{m}$ filtered) bottom water and glutaraldehyde (3\% final concentration) were added. Benthic viruses and bacteria were extracted within $24 \mathrm{~h}$, using a modified protocol from Danovaro et al. (2001), by adding sodium pyrophosphate to a final concentration of $10 \mathrm{mmol}$, followed by $3 \times 1 \mathrm{~min}$ of sonication on an ice bath before centrifugation for $5 \mathrm{~min}$ at $700 \times g$. The settled sediment samples were subsequently washed twice with $2 \mathrm{ml}$ of virus-free water to enhance extractability of bacteria and viruses, and the extracted volumes were pooled with the above mentioned supernatant samples. Aliquots were then diluted 100 to 250 times, and $200 \mu \mathrm{l}$ of extracted samples were taken for slide preparation and analyzed by means of the procedures described above for bacterial and viral abundances.

Phage infection. In glutaraldehyde-fixed experimental samples, bacterial cells contained in $8 \mathrm{ml}$ water samples were collected on copper electron microscope (EM) grids (400 mesh, carbon-coated Formvar film) by centrifugation according to Sime-Ngando et al. (1996).
Each grid was stained at room temperature (ca. $20^{\circ} \mathrm{C}$ ) for $30 \mathrm{~s}$ with uranyl acetate $(2 \% \mathrm{w} / \mathrm{w})$, rinsed twice with $0.02 \mu \mathrm{m}$ filtered distilled water and dried on a filter paper. Grids were examined in a JEM 1200 EX transmission electron microscope (TEM) (JEOL) operated at $80 \mathrm{kV}$ at a magnification of 20000 to $60000 \times$ to distinguish between prokaryotic cells with and without intracellular viruses. A prokaryote was considered infected when at least 5 viruses, identified by their shape and size, were clearly visible inside the host cell. At least 500 prokaryote cells were inspected per grid to determine the frequency of visibly infected cells (FVIC). Because mature phages are visible only late in the infection cycle, FVIC counts were converted to the frequency of infected cells (FIC) using the equation FIC $=9.524 \times$ FVIC -3.256 (Weinbauer et al. 2002) Assuming a steady state existed, that is, the infected and uninfected cells were grazed at the same rate, and that the latent period equalled the prokaryotic generation time, the FIC were converted to bacterial mortality (VIBM, as percentage of prokaryotic production) using the equation: $\mathrm{VIBM}=\left(\mathrm{FIC}+0.6 \times \mathrm{FIC}^{2}\right) /(1-1.2 \times \mathrm{FIC})$ (Binder 1999). For determination of FVIC in sediment samples, the aliquots of water samples extracted from sediments were filtered through $3 \mu \mathrm{m}$ filters and diluted 2 to 8 times before bacteria were harvested on EM grids (Middelboe et al. 2003). For sediment samples, a minimum of 800 cells were inspected per grid to determine FVIC. The mean viral burst size (no. viruses bacterial cell $^{-1}$ ) was estimated for each sample by counting the number of viral particles in a minimum of 15 and 5 visibly infected bacteria in water and sediment samples, respectively.

Statistical analysis. Differences in physicochemical and biological variables between sampled depths and seasons (Spring: March to June, Summer: June to September, Autumn: September to November) were tested by 2-way ANOVA. Potential relationships among variables were tested by linear pairwise correlations (i.e. Pearson correlation analysis) and stepwise multiple regressions. Data were log transformed to satisfy the requirements of normality and homogeneity of variance necessary for parametric statistics. All statistical analyses were performed with Release 12 software for Windows (Minitab).

\section{RESULTS}

\section{Temperature and dissolved oxygen}

Water temperature showed strong seasonal changes ( $p<0.001$ ); the values increased from $7.9^{\circ} \mathrm{C}$ (April) to $22.3^{\circ} \mathrm{C}$ (August) in the surface waters (0.5 $\mathrm{m}$ depth) and then gradually decreased to $15.6^{\circ} \mathrm{C}$ in October. A 
similar trend was also observed at 5 and $10 \mathrm{~m}$ depths, but with lower values (Table 1). Temperature at $40 \mathrm{~m}$ depth was low and less variable $\left(4.9\right.$ to $\left.7.2^{\circ} \mathrm{C}\right)$ with an average $\pm \mathrm{SD}$ of $6.4 \pm 0.7^{\circ} \mathrm{C}$. Thermal stratification started in late April with a weak thermocline at $30 \mathrm{~m}$ (Fig. 2A). The water column above $10 \mathrm{~m}$ depth was generally well oxygenated $\left(>6 \mathrm{mg} \mathrm{O}_{2} \mathrm{l}^{-1}\right.$ ) during the entire study period, contrasting with the deep anoxic zone (i.e. $40 \mathrm{~m}$ ) and the sediments as well. The anoxic layer increased with seasons, from about $38 \mathrm{~m}$ depth in spring to $<30 \mathrm{~m}$ from late August onwards (Fig. 2B).

\section{Nutrients}

In most cases, nutrients did not vary significantly with seasons or with depths. Concentrations of potentially limiting nutrients such as dissolved reactive phosphate and ammonium were well above the threshold concentration to induce any kind of limitation for the growth of planktonic organisms (Table 1). The ammonia concentration in the anoxic zone was significantly higher $(\mathrm{p}<$ 0.001) than in the oxic zone. Concentrations of other nutrients were generally higher in the anoxic waters and sediments than in the upper water column, but differences were not significant.

\section{Chl $a$ and phaeopigments}

Chl a concentration showed large variability with seasons (coefficient of variation $[\mathrm{CV}]=199 \%$ ) and depths $(\mathrm{CV}=171 \%)$. At the $0.5 \mathrm{~m}$ depth, there were 2 peaks of chl $a$, one in April $\left(15.5 \mu \mathrm{g} \mathrm{l}^{-1}\right)$ and a larger one in June (56.1 $\mu \mathrm{g} \mathrm{l}^{-1}$ ) coinciding with the spring phytoplankton bloom. Chl $a$ in the oxic depths (mean \pm $\left.\mathrm{SD}=6.6 \pm 12.2 \mu \mathrm{g} \mathrm{l}^{-1}\right)$ differed significantly $(\mathrm{p}<0.02)$ from those in the anoxic zone $\left(0.6 \pm 1.7 \mu \mathrm{g} \mathrm{l}^{-1}\right)$ (Table 1). Phaeopigment concentrations showed large variability $(\mathrm{CV}=143 \%)$ in the anoxic zone $(40 \mathrm{~m})$, and the values were significantly higher $(p<0.01)$ than in the upper oxic waters. The average phaeopigment concentrations in the oxic and deep anoxic waters were $15.2 \pm 15.7$ and $69.9 \pm 93.7 \mu \mathrm{g} \mathrm{l}^{-1}$, respectively.

\section{Standing stocks}

In the water column, VA and BA peaked on 6 August in the surface waters at $0.5 \mathrm{~m}\left(\mathrm{VA}=3.5 \times 10^{10} \mathrm{l}^{-1}\right.$; $\mathrm{BA}=$ $7.4 \times 10^{9}$ cells $\left.^{-1}\right)$ and $5 \mathrm{~m}\left(\mathrm{VA}=3.0 \times 10^{10} \mathrm{l}^{-1} ; \mathrm{BA}=6.3 \times\right.$ $10^{9}$ cells $\mathrm{l}^{-1}$ ), which was 2 - and 4 -fold higher than the lowest mean value obtained in autumn for all sampling depths $\left(\mathrm{VA}=1.3 \times 10^{10} \mathrm{l}^{-1} ; \mathrm{BA}=1.9 \times 10^{9}\right.$ cells $\mathrm{l}^{-1}$ ) (Fig. 3A,B). Two-way ANOVA indicated that both VA and BA exhibited strong variability $(p<0.001)$ with seasons and depths, both of which interacted significantly (for all microbial variables) because of the spatial differences that occurred during the period of thermal stratification (Table 2, Fig. 3). Among abiotic variables, temperature indeed exerted a significant influence on BA $(\mathrm{p}<0.001)$ and VA $(\mathrm{p}<0.01)$ in the surface oxic waters (Table 3). BA and VA were strongly correlated in these waters (Table 3). VA and BA in the euphotic zone (i.e. at 0.5 and $5 \mathrm{~m}$ ) were significantly $(\mathrm{p}<0.001)$ higher than in the aphotic zone (10 and $40 \mathrm{~m}$ ). In the sediments, both VA and BA were one order of magnitude higher than in the water column (Table 1). Unlike the water

Table 1. Mean (\% coefficient of variation) physicochemical characteristics, chl $a$, phaeopigment concentrations and bacterial and viral variables in the water column and sediments of Lake Grangent, France, from March to November 2007; na: no data available

\begin{tabular}{|c|c|c|c|c|c|c|}
\hline \multirow{2}{*}{ Variable } & \multicolumn{4}{|c|}{ - Oxic } & \multicolumn{2}{|c|}{ - Anoxic } \\
\hline & $0.5 \mathrm{~m}$ & $5 \mathrm{~m}$ & $10 \mathrm{~m}$ & Average & $40 \mathrm{~m}$ & Sediments \\
\hline Temperature $\left({ }^{\circ} \mathrm{C}\right)$ & $17.5(26)$ & $16.9(25)$ & $16.5(26)$ & $16.9(25)$ & $6.4(10)$ & na \\
\hline Dissolved oxygen $\left(\mathrm{mg} \mathrm{l}^{-1}\right)$ & $8.9(22)$ & $8.0(22)$ & $7.6(25)$ & $8.2(23)$ & $1.1(197)$ & na \\
\hline Oxygen saturation $(\%)$ & $98.5(22)$ & $86.7(17)$ & $81.3(17)$ & $88.8(19)$ & $9.4(191)$ & na \\
\hline $\mathrm{NH}_{4}-\mathrm{N}\left(\mathrm{mg} \mathrm{l}^{-1}\right)$ & $0.07(51)$ & $0.07(58)$ & $0.08(65)$ & $0.07(58)$ & $0.8(65)$ & $1.5(40)$ \\
\hline $\mathrm{NO}_{3}-\mathrm{N}\left(\mathrm{mg} \mathrm{l}^{-1}\right)$ & $2.6(37)$ & $2.6(31)$ & $2.7(38)$ & $2.6(35)$ & $3.1(47)$ & $3.1(46)$ \\
\hline $\mathrm{PO}_{4}-\mathrm{P}\left(\mathrm{mg} \mathrm{l}^{-1}\right)$ & $0.05(117)$ & $0.1(60)$ & $0.11(59)$ & $0.09(79)$ & $0.03(55)$ & $0.1(40)$ \\
\hline $\mathrm{SiO}_{2}\left(\mathrm{mg} \mathrm{l}^{-1}\right)$ & $7.1(32)$ & $7.4(33)$ & $7.8(33)$ & $7.4(33)$ & $8.3(10)$ & $8.3(17)$ \\
\hline Chl $a\left(\mu \mathrm{gl}^{-1}\right)$ & $9.7(200)$ & $8.5(180)$ & $1.5(133)$ & $6.6(171)$ & $0.6(119)$ & na \\
\hline Phaeopigments $\left(\mu \mathrm{g} \mathrm{l}^{-1}\right)$ & $19.6(143)$ & $14.4(69)$ & $11.4(79)$ & $15.1(97)$ & $70(134)$ & na \\
\hline Viral abundance $\left(10^{10} \mathrm{l}^{-1}\right)$ & $2.2(24)$ & $2.1(17)$ & $1.6(22)$ & $2.0(21)$ & $1.2(19)$ & $48.2(21)$ \\
\hline Bacterial abundance $\left(10^{9}\right.$ cells $\left.l^{-1}\right)$ & $4.3(32)$ & $4.1(24)$ & $3.0(27)$ & $3.8(28)$ & $2.5(22)$ & $45.5(25)$ \\
\hline Virus-to-bacteria ratio & $5.3(18)$ & $5.2(19)$ & $5.5(23)$ & $5.3(20)$ & $5.8(27)$ & $10.6(85)$ \\
\hline Frequency of infected cells (\%) & $18.8(42)$ & $16.9(50)$ & $14.3(27)$ & $16.7(34)$ & $7.9(32)$ & $2.8(32)$ \\
\hline Viral induced bacterial mortality (\%) & $27.0(60)$ & $23.3(70)$ & $18.7(36)$ & $23.0(55)$ & $9.1(37)$ & $3.0(73)$ \\
\hline Burst size (no. viruses bacterial cell ${ }^{-1}$ ) & $29.0(27)$ & $27.1(34)$ & $23.1(49)$ & $26.4(37)$ & $23.2(41)$ & $16.2(20)$ \\
\hline
\end{tabular}




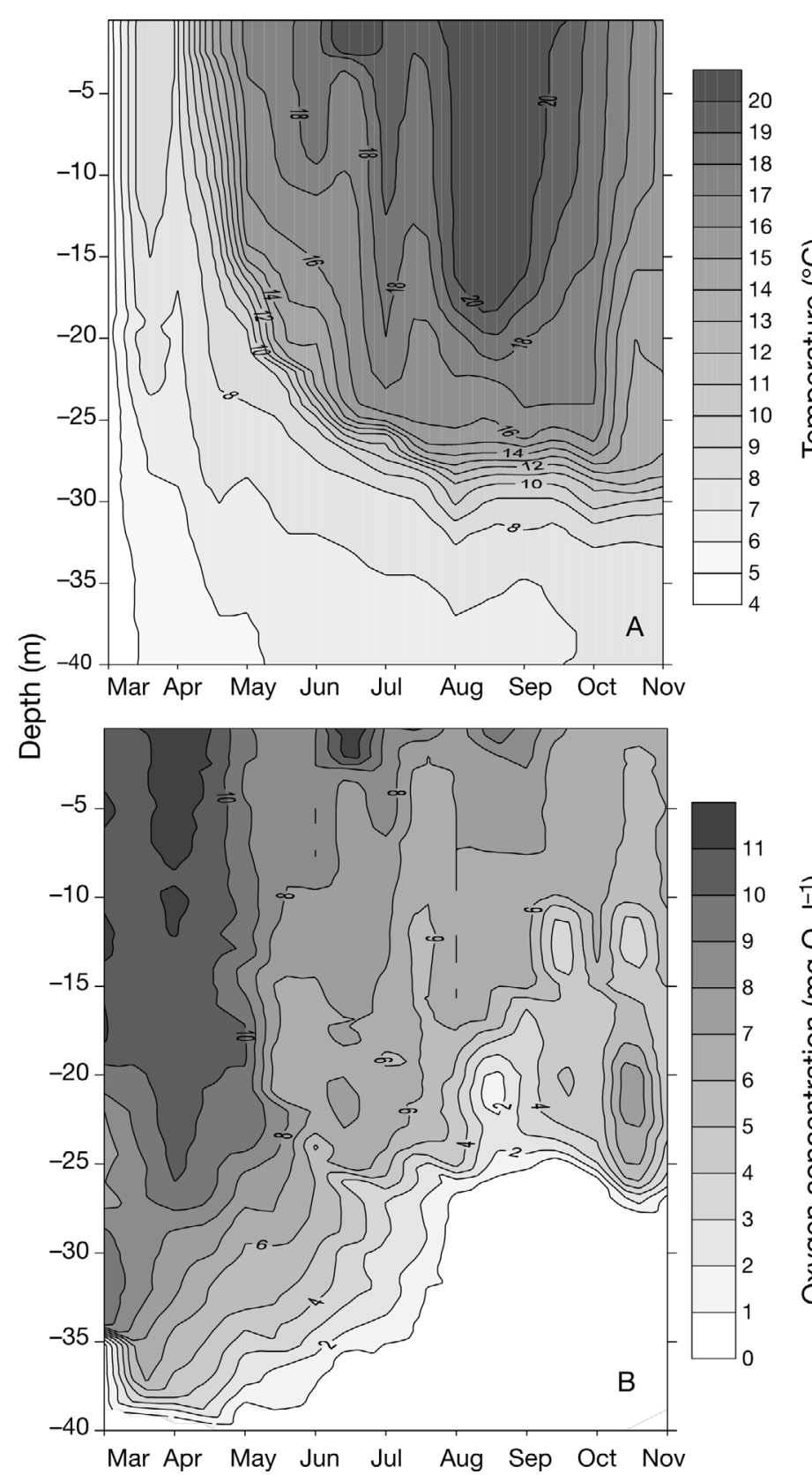

Fig. 2. Spatio-temporal variations of (A) temperature and (B) dissolved oxygen concentration in the water column of Lake Grangent from March to November 2007 column, the highest values for VA $\left(66.5 \times 10^{10} \mathrm{l}^{-1}\right)$ and BA $\left(67.0 \times 10^{9}\right.$ cells $\left.^{-1}\right)$ in the sediments did not occur at the same time (Fig. 3A,B). Despite large variability, VBR did not differ significantly between the sampling depths, averaging 5.3 and 5.8 for oxic and anoxic waters, respectively. In the sediments, VBR (mean = 10.6) was significantly $(\mathrm{p}<0.001)$ higher compared with the water column values (Table 1).

\section{Phage infection and burst size}

The FIC in the oxic waters varied in the range of 5.8 to $34.5 \%$, with a mean value of $16.7 \%$ that corresponded to $23 \%$ of the bacterial mortality caused by viruses (i.e. VIBM). Maxima in FIC at $0.5 \mathrm{~m}$ were observed on 6 August, which coincided with peaks in VA and BA (Fig. 3C) and corresponded to a VIBM level of $71 \%$. FIC in the oxic waters was about 2 -fold and significantly $(\mathrm{p}<0.001)$ higher than in the anoxic water at $40 \mathrm{~m}$ depth (range: 5.8 to $12.8 \%$, mean $=7.9 \%$ ) (Fig. 3C, Table 1). In the oxic waters, FIC was strongly correlated with VA and BA (Table 3). The significantly higher levels of VA and BA in the sediments (i.e. compared with the water column) did not result in higher viral infection. FIC values in the sediments (range: 0.6 to $6.3 \%$, mean $=2.8 \%$ ) were, on average, 3 - to 7 -fold lower $(\mathrm{p}<0.001)$ than in the water column (Table 1$)$. Burst size (BS) varied from 6 to 160 viruses bacterial cell ${ }^{-1}$ with an average value of 26 and 23 viruses cell ${ }^{-1}$ in the oxic and anoxic waters, respectively. The difference between the 2 zones was not significant. In the sediments, BS averaged 16.2 viruses cell ${ }^{-1}$ (Table 1) and the values were not significantly different compared with the water column.

A multiple regression analysis was carried out to determine the relative importance of the main correlates for VA and FIC. For the oxic waters, the models for which the highest $\mathrm{R}^{2}$ values were obtained clearly highlight the importance of BA for VA (i.e. VA $=0.62-$ $0.004 \times$ Temp $\left.+0.37 \times \mathrm{BA} \mathrm{R}^{2}=0.78, \mathrm{n}=49\right)$, and of the combination of BA and VA for FIC $(\mathrm{FIC}=3.73+4.51 \times$ $\mathrm{BA}-2.8 \times \mathrm{VA}, \mathrm{R}^{2}=0.35, \mathrm{n}=49$ ). For the anoxic waters and sediments, the measured environmental variables

Table 2. Two-way ANOVA results for the effects of seasons and depths on viral and bacterial abundances, frequency of infected cells and burst size in Lake Grangent. Degrees of freedom are 15, 3, 45 and 128 for A, B, A × B and error, respectively

\begin{tabular}{|c|c|c|c|c|c|c|c|c|}
\hline \multirow[t]{2}{*}{ Source } & \multicolumn{2}{|c|}{ Viruses } & \multicolumn{2}{|c|}{ Bacteria } & \multicolumn{2}{|c|}{ Frequency of infected cells } & \multicolumn{2}{|c|}{ Burst size } \\
\hline & $F$ & $\mathrm{p}$ & $F$ & $\mathrm{p}$ & $F$ & $\mathrm{p}$ & $F$ & $\mathrm{p}$ \\
\hline Seasons (A) & 78.82 & 0.0001 & 444.38 & 0.0001 & 632.72 & 0.0001 & 13.56 & 0.0001 \\
\hline Depths (B) & 4.98 & 0.0001 & 86.72 & 0.0001 & 114.81 & 0.0001 & 15.15 & 0.0001 \\
\hline Interactions $(\mathrm{A} \times \mathrm{B})$ & 5.98 & 0.0001 & 20.28 & 0.0001 & 37.65 & 0.0001 & 10.36 & 0.0001 \\
\hline
\end{tabular}



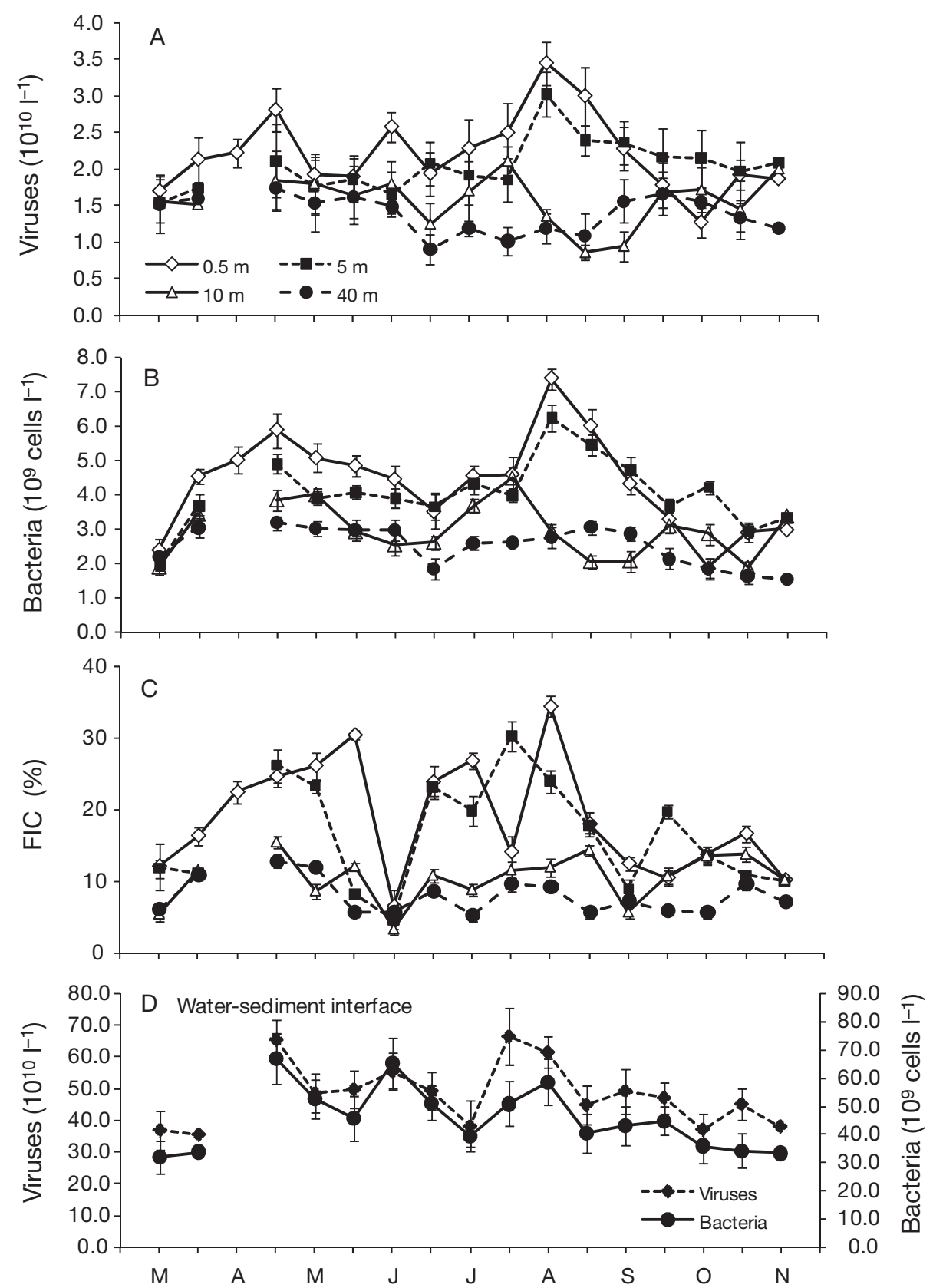

Fig. 3. Viral and bacterial parameters of Lake Grangent, March to November 2007. Spatio-temporal variability in (A) viral abundance and (B) bacteria abundance, and (C) the frequency of infected bacterial cells (FIC) in the water column. (D) Viral and bacterial abundances in the surface sediments $(0$ to $2 \mathrm{~cm})$. Error bars are SE

only explained part of the variance in VA and FIC, but did not yield significant correlates.

\section{DISCUSSION}

\section{Pelagic interactions}

The present study is one of the few of its kind conducted in freshwater reservoirs (Sommaruga et al.
1995, Šimek et al. 2001, Pradeep Ram et al. 2005) and the first study of the eutrophic Lake Grangent that documents the seasonal standing stock of viruses and phage infection in relation to environmental variables in the water column down to the surface sediments. The virioplankton abundances were within the range reported in other lakes (Weinbauer 2004) and similar to those from temperate eutrophic lakes such as Lake Aydat, France (Bettarel et al. 2003), Lake Plußsee, Germany (Weinbauer \& Höfle 1998), and Lake Loosdrecht, 
Table 3. Pearson product moment correlation (r) between different variables in the oxic $(\mathrm{n}=49)$ or anoxic $(\mathrm{n}=16)$ waters during March to November 2007 in Lake Grangent. Levels of significance: ${ }^{*} \mathrm{p}<0.05,{ }^{* *} \mathrm{p}<0.01,{ }^{* * *} \mathrm{p}<0.001$; ns: not significant

\begin{tabular}{|c|c|c|c|c|}
\hline Variable & Temperature & $\begin{array}{c}\text { Bacterial } \\
\text { abundance }\end{array}$ & $\begin{array}{c}\text { Viral } \\
\text { abundance }\end{array}$ & $\begin{array}{c}\text { Frequency } \\
\text { of infected } \\
\text { cells }\end{array}$ \\
\hline \multicolumn{5}{|l|}{ Temperature } \\
\hline Bacterial abundance & $0.48^{* * *} / \mathrm{ns}$ & & & \\
\hline Viral abundance & $0.41^{* *} / \mathrm{ns}$ & $0.89^{* * *} / \mathrm{ns}$ & & \\
\hline $\begin{array}{l}\text { Frequency of } \\
\text { infected cells }\end{array}$ & $\mathrm{ns} / \mathrm{ns}$ & $0.68^{* * *} / 0.59^{* *}$ & $0.58^{* * *} / \mathrm{ns}$ & \\
\hline Burst size & ns & $\mathrm{ns} / 0.47^{*}$ & $\mathrm{~ns} / \mathrm{ns}$ & $0.30 * / \mathrm{ns}$ \\
\hline
\end{tabular}

The Netherlands (Tijdens et al. 2008). Concentrations of both viruses and bacteria in the oxygenated waters differed significantly from those at the anoxic depth (i.e. $40 \mathrm{~m}$ ), a situation that also corroborates findings in eutrophic waters (Jiang et al. 2004). In Lake Grangent, the spatial differences were partly forced by thermal stratification together with dramatic differences between oxic and anoxic waters in terms of dissolved oxygen, ammonia concentration and phytoplankton biomass. Indeed, viral and bacterial abundances were significantly correlated to water temperature and to each other as well, but the latter correlation was clearly due to the patterns recorded in oxygenated depths ( $R^{2}=0.78$ versus 0.11 in anoxic waters). In the oxic waters, bacteria thus appeared to be the major hosts for viruses, as is generally known from temperate lakes (Bettarel et al. 2003, Pradeep Ram et al. 2005). Overall, the seasonal abundances of both viruses and bacteria in Lake Grangent were rather homeostatic as they did not vary by more than 5 -fold for all sampled depths (Fig. 3A,B), which is similar to those reported by Mathias et al. (1995) in a backwater system of River Danube and Hennes \& Simon (1995) in the mesotrophic Lake Constance, Germany. The VBR also did not fluctuate greatly (range: 4 to 8 ) over the study period, suggesting a tight coupling between bacteria and viruses and a relatively constant level of viral production and loss (Pradeep Ram et al. 2005).

Recent studies have suggested that viral infection may contribute significantly to bacterial mortality in aquatic systems, and FVIC is a measure of the magnitude of this process (Pradeep Ram et al. 2005, Gobler et al. 2008). We used TEM methods (i.e. whole cell examination) to determine FVIC (expressed as percentage of total prokaryotic cells), which provides direct evidence of phage infection. As most of the data to date on FVIC and burst sizes are derived from TEM-based estimates (Weinbauer 2004), comparison among aquatic systems are relatively easy. Discussions about inter- preting the estimates of bacterial mortality due to viral lysis based on the whole cell FVIC approach are detailed in Weinbauer \& Höfle (1998), GuixaBoixereu et al. (1999), and Bettarel et al. (2004), and thus, will not be reiterated here. However, because a minimum of 500 to 800 cells were examined for 0.6 to $3.9 \%$ target-infected cells, our FVIC values in the lower range would be error prone due to the general rarity of infected cells, especially in the sediment samples (SimeNgando \& Colombet 2009).

In the plankton of Lake Grangent, FVIC values were comparable and within the typical range (i.e. $<5 \%$ ) reported for limnetic systems (Sime-Ngando et al. 2003, Weinbauer 2004). Similar to viral and bacterial abundances, significant difference in viral infection was observed between oxic and anoxic waters, probably because of dramatic changes in the availability of hosts and the factors that control their abundance and activity in oxic versus anoxic environments (DeBruyn et al. 2004, Gobler et al. 2008). Such depth-related differences have been poorly resolved in stratified productive lakes such as Lake Aydat, France, (Bettarel et al. 2003) and Mono Lake, USA (Brum et al. 2005). On average the viral infection rate was 2-fold higher in the oxic than in anoxic waters. This vertical pattern that we found in Lake Grangent differs from previous results obtained in other stratified water bodies, where studies have found that viral lysis is more prominent in the anoxic than in the oxic waters (Weinbauer \& Höfle 1998, Colombet et al. 2006, Gobler et al. 2008). Viral production might be suppressed in the deeper layer of Lake Grangent because of low bacterial activity (as indicated by low bacterial abundance) and depletion of dissolved oxygen (average concentration at $40 \mathrm{~m}$ depth $=1.1 \mathrm{mg} \mathrm{O}_{2} \mathrm{l}^{-1}$ ). In addition to the anoxia, studies on bacterial community composition could also help explain the variability in viral infection rates. Although viruses apparently contributed little to bacterial mortality in anoxic waters and sediments in our study, they can exert a strong influence on clonal diversity of bacteria in such environments by selecting for virus resistant strains.

The increase in viral infection with increasing VA and BA would suggest that the lytic mode of infection is important in Lake Grangent, primarily in the oxygenated waters where viral proliferation leads to high encounter rates between viruses and their heterotrophic bacterial hosts. This implies that the bacterioplankton community could be dominated by only a few species, favoring specific adsorption of viruses to their 
co-occurring hosts, and that the maintenance of a high number of viruses is dependent on active bacterioplankton populations (Weinbauer 2004, Pradeep Ram et al. 2005). Multiple regression analysis suggested that the predictability of FIC from VA and BA was weak $\left(\mathrm{R}^{2}\right.$ $=0.35$ ) and substantially lower than that of VA from BA $\left(R^{2}=0.78\right)$. One explanation assumes that a portion of the viral community in Lake Grangent infects cyanobacterial hosts (A. S. Pradeep Ram unpubl.). Cyanobacteria are highly abundant in Lake Grangent (Latour et al. 2004), and they can also represent major viral hosts in pelagic environments (cf. Sime-Ngando \& Colombet 2009). So, the chance for viral proliferation is linearly dependent on the density of abundant and susceptible hosts, i.e. both auto- and heterotrophic prokaryotes (Murray \& Jackson 1992). An alternative explanation would be that viral infection is not as host specific as previously assumed, or it may depend on the environmental conditions that influence receptor expression on host cell surfaces.

Calculations based on the model by Weinbauer et al. (2002) and Binder (1999) suggest that, on average, 17 and $8 \%$ (i.e. FIC) of bacteria in oxic and anoxic waters, respectively, were infected by viruses in Lake Grangent. This corresponds to about 23 and $9 \%$, respectively, (i.e. VIMB) of bacterial production being destroyed by viruses. Depth-related differences in viral lysis could be linked to bacterial diversity, thus tempting us to assume that host genetic diversity might be important in controlling viral infection rates. High ammonia concentration in the anoxic bottom waters is the consequence of ammonia build-up in the water-sediment interface, primarily due to degradation of phytoplankton biomass as evidenced by high phaeopigment concentrations. These zones could be dominated by ammonia oxidizing bacteria capable of anaerobic oxidation of ammonium (Freitag \& Prosser 2003), a process that has been less studied in deep anoxic freshwaters. Such zones could also harbor many novel non-extreme environmental Archaea, which have been previously reported in eutrophic lakes (Jurgens et al. 2000, Eller et al. 2005).

In Lake Grangent, BS (derived from TEM observation of intracellular phages) varied from 6 to 160 viruses cell ${ }^{-1}$ with an average value of 26 and 23 viruses cell ${ }^{-1}$ for oxic and anoxic waters, respectively. Unlike VA and phage infection, there was no significant difference in BS between the 2 zones, which is consistent with observations in other stratified aquatic environments (Choi et al. 2003, Bettarel et al. 2004, Gobler et al. 2008). However, these results were in contrast to other studies in which BS were found to be significantly larger in anoxic bottom waters relative to the overlying oxic waters (Weinbauer \& Höfle 1998, Weinbauer et al. 2003). Similar to observations reported for Lake Erie, USA (Gobler et al. 2008), no consistent pattern seemed to emerge in our study concerning the vertical variability in BS, and the few data available prevent us from making any simple generalization. The transmission electron micrographs of viral infected cells (Fig. 4) reveal that the BS observed in Lake Grangent samples were indeed much lower than the global average of 34 and 57 viruses cell ${ }^{-1}$ reported for freshwaters and eutrophic waters, respectively (Prada et al. 2006). Low BS could be explained when lytic phages have a short latent period due to short host generation time, or when host abundances are high (Prada et al. 2006). Nevertheless, BS could also be influenced by a number of factors, such as the size of viruses or the size and metabolic activity of hosts.

\section{Benthic interactions}

The present understanding that viruses are more abundant in aquatic sediments than in the overlying water column (Fischer et al. 2003, Mei \& Danovaro 2004, Bettarel et al. 2006) was confirmed in our study. The origin of the high abundances of viruses in aquatic sediments is still an uncertainty, particularly when we take into account the low occurrence of visibly infected cells in TEMs and the related low bacteriolysis reported in geographically contrasting environments, which include tropical (Bettarel et al. 2006), temperate (Filippini et al. 2006, the present study) and subarctic (C. Säwström et al. unpubl.) lake sediments. If benthic bacteria are not susceptible to viral infection, then the high concentrations of viruses in the sediments may be due to sedimentation, accumulation and persistence of viruses that originated from the surface waters (Bettarel et al. 2006). In our sediment samples, the low levels of FVIC (i.e. $<0.6 \%$ ) could not be entirely attributed to methodological bias, given that higher levels were detected in pelagic bacteria. In all sediment samples analyzed, bacteria were clearly identifiable on the basis of staining quality, cell transparency and membrane refringence. However, uncertainties remain because filtration (through $3 \mu \mathrm{m}$ membranes) or the sonication procedure used to extract bacteria from sediments may result in loss or disruption of cells, and this effect may be more pronounced with large-sized fragile infected cells (Bettarel et al. 2006).

Bacteria are known to be very active in sediments (Kirschner \& Velimirov 1999, Haglund et al. 2003), but the reasons why they are less susceptible to viral infection are unclear and need to be elucidated. Our low FVIC-derived viral lysis in sediment bacteria together with those reported in other lake sediments using the same methodological approach (i.e. Bettarel et al. 2006, Filippini et al. 2006, C. Säwström et al. 


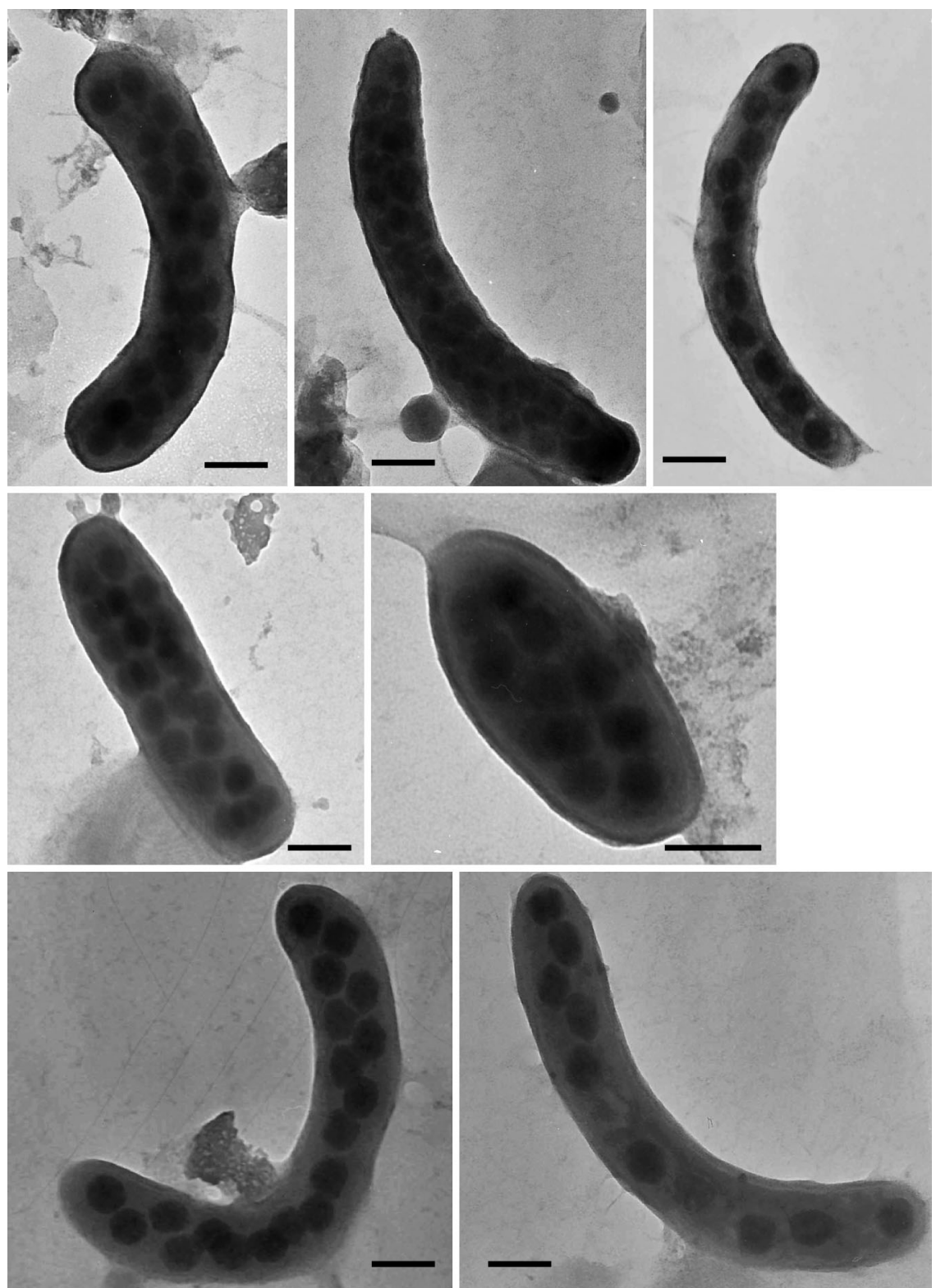

Fig. 4. Transmission electron micrographs of typical infected bacterial cells from the productive Lake Grangent with low and varying burst sizes, i.e. the number of intracellular viruses per infected cell. Each scale bar denotes $100 \mathrm{~nm}$

unpubl.) are indications that strengthen the nation that aquatic sediments provide good conditions for viral preservation, but paradoxically, are poor environments for viral proliferation. In such environments, lysogeny could be a predominant mode of infection, but this still needs to be demonstrated. A prevalence of temperate viruses in aquatic sediments may indeed immune-suppress lytic viral attacks, resulting in low FVIC levels. Viral proliferation in sediments may also be limited by physical or biochemical conditions that prevent high encounter rates (Fischer et al. 2004, Fil- ippini et al. 2006). Massive adsorption of viruses on sediment particles may also weaken their infectivity (Hewson \& Fuhrman 2003), alter the physiology of bacteria and, to an unknown extent, render host cells more resistant to viral attack (Fischer et al. 2003). Alternatively, diverse prokaryotic communities within aquatic sediments (Torsvik et al. 2002) may represent a barrier for viral proliferation. Further studies on the changes in microbial community composition with time and space would be useful in the context of the viral ecology of Lake Grangent. 


\section{CONCLUSIONS}

Overall, our study presents the first data on seasonal abundance and lytic activity of viruses in the water column down to the surface sediments of the eutrophic Lake Grangent, France. The abundances of viruses and bacteria were one order of magnitude higher in the sediments than in the water column. Astonishingly, the viral-to-bacterial abundance was rather stable in the water column, independently of the oxygen concentration, but was twice as high and more variable in the sediments. However, few visibly infected bacteria, and the related bacteriolysis $(<10 \%$ of bacterial production), occurred in the deep anoxic waters and sediments, compared with the surface oxic waters. In these waters, about one quarter of bacterial production ended up in viral synthesis, indicating that a significant portion of organic matter could be recycled via the viral shunt into regenerated nutrients in the lake. In such a eutrophic turbid reservoir where cyanobacterial blooms are recurrent, viral-derived cell lysis products could also act like glue for the formation of organic aggregates and facilitate sinking of aggregates (Proctor \& Fuhrman 1991), thereby resulting in the accumulation of pelagic organic particles into the sediments. Together with other factors such as changes in host diversity, this may account, at least partly, for the low effect of viruses on bacteria in the deep anoxic waters and sediments of the Lake Grangent reservoir.

Acknowledgements. A.S.PR and M.S. were supported by postdoctoral and doctoral fellowships, respectively, from the French Agence Nationale de la Recherche (ANR) and Electricite de France (EDF). This is a contribution to the Research Programs ACI/FNS ECCO VIRULAC (TSN) and ANR Biodiversité AQUAPHAGE (ASPR, TSN). We gratefully acknowledge support from EDF to D.L. and thank P. Sauvignet and A. Thouvenot for their logistic, technical and field assistance. We appreciate valuable comments and suggestions from 3 reviewers.

\section{LITERATURE CITED}

AFNOR (Association Française de Normalisation) (1990) Eaux, méthodes d'essais: recueil de normes françaises, Union Imprimerie Paragraphic, Paris

Bergh O, Borsheim KY, Bratbak G, Heldal M (1989) High abundance of viruses found in aquatic environments. Nature 340:467-468

Berthon JL, Devaux J, Aleya L, Giraudet H, Restituito F (1996) Déterminisme de l'eutrophisation de la retenue de Grangent (Loire): étude des apports en nutriments, de la dynamique des populations phytoplanctoniques et des relations phyto-zooplancton en 1990-1991. Hydroécol Appl 8:99-125

Bettarel Y, Sime-Ngando T, Amblard C, Carrias JF, Portelli C (2003) Virioplankton and microbial communities in aquatic systems: a seasonal study in two lakes of differing trophy. Freshw Biol 48:810-822
Bettarel Y, Sime-Ngando T, Amblard C, Dolan J (2004) Viral activity in two contrasting lake ecosystems. Appl Environ Microbiol 70:2941-2951

Bettarel Y, Bouvy M, Dumont C, Sime-Ngando T (2006) Virusbacterium interaction in water and sediments of West African inland aquatic ecosystems. Appl Environ Microbiol 72:5274-5282

Binder B (1999) Reconsidering the relationship between virally induced bacterial mortality and frequency of infected cells. Aquat Microb Ecol 18:207-215

Brum JR, Steward GF, Jiang SC, Jellison R (2005) Spatial and temporal variability of prokaryotes, viruses, and viral infections of prokaryotes in an alkaline, hypersaline lake. Aquat Microb Ecol 41:247-260

Brussaard CPD, Wilhelm SW, Thingstad F, Weinbauer MG and others (2008) Global scale processes with a nanoscale drive-from viral genes to oceanic biogeochemical cycles. ISME J 2:575-578

Choi DH, Hwang CY, Cho BC (2003) Comparison of virusand bacterivory-induced bacterial mortality in the eutrophic Masan Bay, Korea. Aquat Microb Ecol 30: $117-125$

Colombet J, Sime-Ngando T, Cauchie HM, Fonty G, Hoffmann L, Demeure G (2006) Depth-related gradients of viral activity in Lake Pavin. Appl Environ Microbiol 72:4440-4445

> Danovaro R, Dell'anno A, Trucco A, Serresi M, Vanucci S (2001) Determination of virus abundance in marine sediments. Appl Environ Microbiol 67:1384-1387

DeBruyn JM, Leigh-Bell JA, Mckay RML, Bourbonniere RA, Wilhelm SW (2004) Microbial distributions and the impact of phosphorus on bacterial activity in Lake Erie. J Gt Lakes Res 30:166-183

Eller G, Layla K, Martin K (2005) Concurrence of aerobic and anaerobic methane oxidation in the water column of Lake Plußsee. Appl Environ Microbiol 71:8925-8928

- Filippini M, Buesing N, Bettarel Y, Sime-Ngando T, Gessner M (2006) Infection paradox: high abundance but low impact of freshwater benthic viruses. Appl Environ Microbiol 72:4893-4898

- Fischer UR, Velimirov B (2002) High control of bacterial production by viruses in a eutrophic oxbow lake. Aquat Microb Ecol 27:1-12

Fischer UR, Wieltschnig C, Kirschner AKT, Velimirov B (2003) Does virus-induced lysis contribute significantly to bacterial mortality in the oxygenated sediment layer of shallow oxbow lakes? Appl Environ Microbiol 69:5281-5289

> Fischer UR, Weisz W, Wieltschnig C, Kirschner AKT, Velimirov B (2004) Benthic and pelagic viral decay experiments: a model-based analysis and its applicability. Appl Environ Microbiol 70:6706-6713

> Freitag TE, Prosser JI (2003) Community structure of ammonia-oxidizing bacteria within anoxic marine sediments. Appl Environ Microbiol 69:1359-1371

Giraudet H, Berthon JL (1999) Rapport annuel du suivi de la communaute' planctonique de la retenue de Grangent et de l'e'tude de l'e'tat physiologique des Cyanobacte'ries lors du processus de de'veloppement des fleurs d'eau. Electricité de France, Agence de l'Eau Loire-Bretagne, Saint-Etienne

> Gobler CJ, Davis TW, Deonarine SN, Saxton MA, Lavrentyev PJ, Jochem FJ, Wilhelm SW (2008) Grazing and virusinduced mortality of microbial populations before and during the onset of annual hypoxia in Lake Erie. Aquat Microb Ecol 51:117-128

- Guixa-Boixereu N, Lysnes K, Pedrós-Alió C (1999) Viral lysis and bacterivory during a phytoplankton bloom in a 
coastal water microcosm. Appl Environ Microbiol 65: 1949-1958

Haglund AL, Lantz P, Tornblom E, Tranvik L (2003) Depth distribution of active bacteria and bacterial activity in lake sediment. FEMS Microbiol Ecol 46:31-38

Hennes KP, Simon M (1995) Significance of bacteriophages for controlling bacterioplankton growth in a mesotrophic lake. Appl Environ Microbiol 61:333-340

Hewson I, Fuhrman JA (2003) Viriobenthos production and virioplankton sorptive scavenging by suspended sediment particles in coastal and pelagic water. Microb Ecol 46: 337-347

Jiang S, Steward GF, Jellison R, Chu W, Choi S (2004) Abundance, distribution and diversity of viruses in alkaline, hypersaline, Mono Lake, California. Microb Ecol 47:9-17

> Jurgens G, Glockner FO, Aman R, Saano A, Montonen L, Likolammi M, Munster U (2000) Identification of novel Archaea in bacterioplankton of a boreal forest lake by phylogenetic analysis and fluorescent in situ hybridization. FEMS Microbiol Ecol 34:45-56

Kirschner AKT, Velimirov B (1999) Benthic bacterial secondary production measured via simultaneous ${ }^{3} \mathrm{H}$-thymidine and ${ }^{14} \mathrm{C}$-leucine incorporation, and its implication for the carbon cycle of a shallow macrophyte dominated backwater system. Limnol Oceanogr 44:1871-1881

Latour D, Sabido O, Salencon MJ, Giraudet H (2004) Dynamics and metabolic activity of the benthic cyanobacterium Microcystis aeruginosa in the Grangent Reservoir (France). J Plankton Res 26:719-726

Lorenzen CJ (1967) Determination of chlorophyll and phaeopigments: spectrophotometric equation. Limnol Oceanogr 12:343-346

Mathias CB, Kirschner KT, Velimirov B (1995) Seasonal variations of virus abundance and virus control of the bacterial population in a backwater system of the Danube River. Appl Environ Microbiol 61:3734-3740

Mei ML, Danovaro R (2004) Virus production and life strategies in aquatic sediments. Limnol Oceanogr 49:459-470

Middelboe M, Glud RN, Finster K (2003) Distribution of viruses and bacteria in relation to diagenetic activity in an estuarine sediment. Limnol Oceanogr 48:1447-1456

Middelboe M, Jacquet S, Weinbauer MG (2008) Viruses in freshwater ecosystems: an introduction to the exploration of viruses in new aquatic habitats. Freshw Biol 53: 1069-1075

> Motomizu S, Toshiaki W, Kyoji T (1983) Spectrophotometric determination of phosphate in river waters with molybdate and malachite green. Analyst 108:361-367

- Murray AG, Jackson GA (1992) Viral dynamics: a model of the effects of size, shape, motion and abundance of singlecelled planktonic organisms and other particles. Mar Ecol Prog Ser 89:103-116

Noble RT, Fuhrman JA (1998) Use of SYBR Green I for rapid epifluorescence counts of marine viruses and bacteria. Aquat Microb Ecol 14:113-118

Pedros-Alio C, Calderon-Paz JI, Gasol JM (2000) Comparative analysis shows bacterivory, not viral lysis, controls the abundance of heterotrophic prokaryotic plankton. FEMS Microbiol Ecol 32:157-165

Parada V, Herndl GJ, Weinbauer MG (2006) Viral burst size of heterotrophic prokaryotes in aquatic systems. J Mar Biol Assoc UK 86:613-621

Editorial responsibility: Gunnar Bratbak, Bergen, Norway
Pradeep Ram AS, Boucher D, Sime-Ngando T, Debroas D, Romagoux JC (2005) Phage bacteriolysis, protistan bacterivory potential, and bacterial production in a freshwater reservoir: coupling with temperature. Microb Ecol 50: $64-72$

Proctor LM, Fuhrman JA (1991) Roles of viral infection in organic particle flux. Mar Ecol Prog Ser 69:133-142

Rodier L (1996) L'analyse de l'eau, eaux naturelles, eaux résiduaires, eau de mer, 8th edn. Dunod, Paris

Sime-Ngando T, Colombet J (2009) Viruses and prophages in the dynamics of aquatic ecosystems. Can J Microbiol 55: 95-109

Sime-Ngando T, Mignot JP, Amblard C, Bourdier G, Devilettes C, Quilblier-Lloberas C (1996) Characterization of planktonic virus-like particles in a French mountain lake: methodological aspects and preliminary results. Ann Limnol 32:1-5

Sime-Ngando T, Bettarel Y, Chartogne C, Sean K (2003) The imprint of wild viruses on freshwater microbial ecology. Recent Res Dev Microbiol 7:481-497

Šimek K, Pernthaler J, Weinbauer MG, Hornak K and others (2001) Changes in bacterial community composition and dynamics and viral mortality rates associated with enhanced flagellate grazing in a mesoeutrophic reservoir. Appl Environ Microbiol 67:2723-2733

Sommaruga R, Krössbacher M, Salvenmoser W, Catalan J, Psenner R (1995) Presence of large virus-like particles in a eutrophic reservoir. Aquat Microb Ecol 9:305-308

> Suttle CA (2007) Marine viruses - major players in the global ecosystem. Nat Rev Microbiol 5:801-812

Tijdens M, Hoogveld HL, Kamst-van Agterveld MP, Simis SGH, Baudoux AC, Laanbroek HJ, Gons HJ (2008) Population dynamics and diversity of viruses, bacteria and phytoplankton in a shallow eutrophic lake. Microb Ecol 56:29-42

> Torsvik V, Øvreas L, Thingstad TF (2002) Prokaryotic diversity-magnitude, dynamics, and controlling factors. Science 296:1064-1066

> Weinbauer MG (2004) Ecology of prokaryotic viruses. FEMS Microbiol Rev 28:127-181

> Weinbauer MG, Höfle MG (1998) Significance of viral lysis and flagellate grazing as factors controlling bacterioplankton production in a eutrophic lake. Appl Environ Microbiol 64:431-438

> Weinbauer MG, Winter C, Höfle MG (2002) Reconsidering transmission electron microscopy based estimates of viral infection of bacterioplankton using conversion factors derived from natural communities. Aquat Microb Ecol 27: 103-110

Weinbauer MG, Brettar I, Hofle MG (2003) Lysogeny and virus-induced mortality of bacterioplankton in surface, deep and anoxic marine waters. Limnol Oceanogr 48: 1457-1465

Wetzel RG (2001) Limnology: lake and river ecosystems, 3rd edn. Academic Press, New York

Wetzel RG, Likens GE (1995) Limnological analysis, 2nd edn. Springer-Verlag, New York

Wilhelm SW, Matteson AR (2008) Freshwater and marine virioplankton: a brief overview of commonalities and differences. Freshw Biol 53:1076-1089

Wilhelm SW, Suttle CA (1999) Viruses and nutrient cycles in the sea. BioScience 49:781-788

Submitted: November 25, 2008; Accepted: March 19, 2009

Proofs received from author(s): May 30, 2009 